\title{
Atopic profile of asthmatic children in Bahrain
}

\author{
K.S. Tabbara, ${ }^{7}$ A. Ibrahim, ${ }^{2,3}$ R. Ajjawi ${ }^{3}$ and F. Saleh ${ }^{1,4}$
}

$$
\text { خالد سعيد طبارة، علي إبرأهبي للأطفال المصابين بالربو ريم عجاوي، فاضل البحرين صالح }
$$

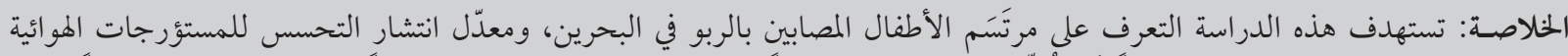

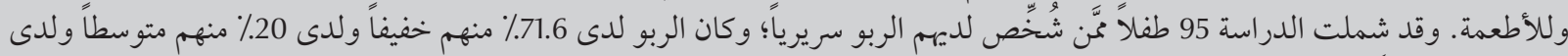

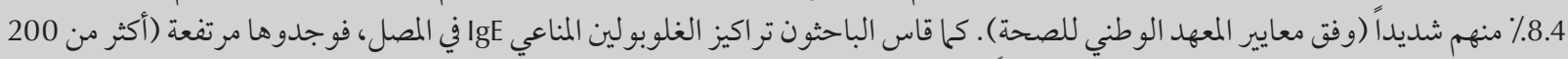

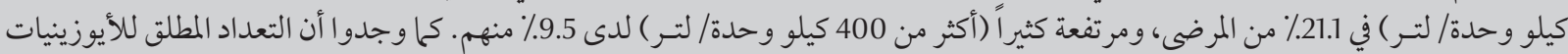

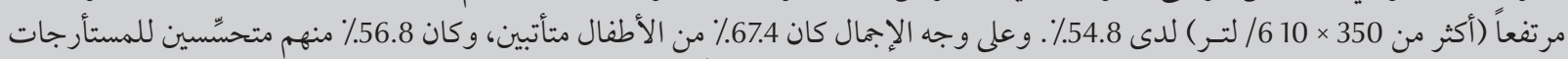

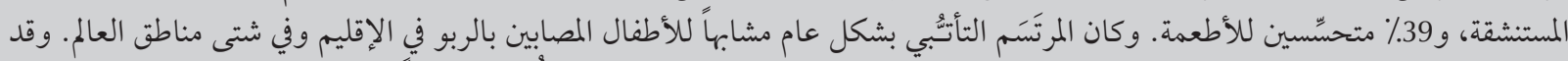

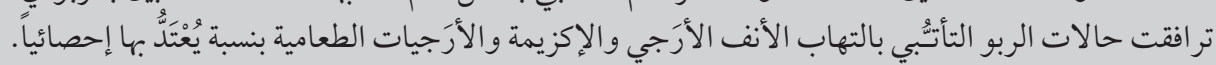

ABSTRACT This study aimed to define the profile of asthmatic children in Bahrain and the prevalence of sensitization to aeroallergens and foods. A total of 95 children who were clinically diagnosed with asthma were enrolled: $71.6 \%$ mild, $20.0 \%$ moderate and $8.4 \%$ severe asthma (NIH criteria). Serum IgE concentrations were elevated (> $200 \mathrm{kU} / \mathrm{L}$ ) in $21.1 \%$ of patients and highly elevated (> $400 \mathrm{kU} / \mathrm{L}$ ) in $9.5 \%$. Absolute eosinophil counts were elevated $\left(>350 \times 10^{6} / \mathrm{L}\right.$ ) in $54.8 \%$. Overall, $67.4 \%$ of children were atopic; $56.8 \%$ were sensitive to inhalant allergens and $39.0 \%$ to foods. The atopic profile was generally similar to asthmatic children in the region and worldwide. Conditions significantly associated with atopic asthma included food allergies, allergic rhinitis and eczema.

\section{Profil atopique des enfants asthmatiques à Bahreïn}

RÉSUMÉ La présente étude avait pour objectif de définir le profil des enfants asthmatiques à Bahreïn et la prévalence de la sensibilisation aux aéroallergènes et à certains aliments. Au total, 95 enfants ayant fait l'objet d'un diagnostic clinique d'asthme ont été inclus dans l'étude. Selon les critères du National Institute of Health, 71,6\% d'entre eux souffraient d'asthme léger, 20,0 \% d'asthme modéré et 8,4\% d'asthme sévère. Les concentrations sériques d'IgE étaient élevées (> $200 \mathrm{kU} / \mathrm{I}$ ) chez $21,1 \%$ des patients et très élevées (> $400 \mathrm{kU} / \mathrm{I}) \mathrm{chez} 9,5 \%$ des enfants. Le nombre absolu d'éosinophiles était élevé (> $\left.350 \times 10^{6} / \mathrm{I}\right)$ chez 54,8 \% des patients de I'étude. Globalement, $67,4 \%$ des enfants étaient atopiques ; 56,8 \% présentaient une sensibilité aux allergènes inhalés et $39,0 \%$ à certains aliments. Le profil atopique des enfants asthmatiques dans la région était généralement similaire au profil des enfants des autres pays dans le monde. Les affections fortement associées à un asthme atopique étaient les allergies alimentaires, la rhinite allergique et l'eczéma.

${ }^{7}$ Department of Microbiology, Immunology and Infectious Diseases; ${ }^{2}$ Department of Paediatrics, College of Medicine and Medical Sciences, Arabian GulfUniversity, Manama, Bahrain (Correspondence to K.S. Tabbara: kst1@batelco.com.bh; khaledst@agu.edu.bh). ${ }^{3}$ Department of Paediatrics; ${ }^{4}$ Department of Pathology, Salmaniya Medical Complex, Ministry of Health, Manama, Bahrain. Received: 15/03/09; accepted: 27/05/09 


\section{Introduction}

Bronchial asthma is one of the commonest multifactorial chronic diseases. The worldwide incidence of asthma has been increasing in frequency and severity in recent years, particularly among children and young adults [1], and it has become a leading cause of emergency department admissions and school absenteeism in children. Atopy is the major predisposing factor for asthma in children. It seems likely that atopy results from a deviation of the immune response towards the activation of $\mathrm{T}$ helper type 2 lymphocytes, resulting in a chronic inflammatory response associated with the induction of $\operatorname{IgE}$ class antibodies and eosinophilia [2].

The main route of allergen exposure in asthma is by inhalation. Common aeroallergens reflect both the indoor as well as the outdoor flora and fauna of a country. Substances that are generally recognized as important inhalant allergens include pollens, mould spores, house dust mites and insect and animal proteins [3-5]. Food allergy, which has been shown to account for $2 \%$ to $8.5 \%$ of the underlying allergies in asthmatic children [6], is frequently overlooked in asthma. The prevalence of food allergies seems to have increased in the last decade and an accurate history is important in identifying food allergies in patients. Diagnostic tests for food allergies include skin testing and foodspecific IgE assay, while oral challenge may be indicated in certain situations. Symptoms of food allergies vary from atopic dermatitis or gastrointestinal symptoms to violent anaphylaxis [7]. Foods that are often implicated in food allergies include egg, milk, nuts, wheat, soya and fish. Sensitization to these is usually acquired in childhood [8].

The desert nature of the Gulf region, coupled with the hot, humid weather predisposes the population to indoor living in an air-conditioned environment for a major part of the year. Reported prevalence rates of asthma in the Gulf Cooperative Council (GCC) population range between $8 \%$ and $23 \%$ [9-12], higher than rates reported in the USA [1] or Europe [13]. Despite the desert environment, pollen is reported to constitute a major sensitizing allergen in several GCC countries [14,15], followed by indoor allergens, including house dust, animal dander and moulds [15-18].

There are no published studies defining the profile of asthmatic children in Bahrain and the contribution of aeroallergens and food allergy to the development of this condition in the residents of Bahrain. This study explored the sociodemographic profile and the environmental living conditions of a sample of asthmatic children in Bahrain, including the prevalence of atopic asthma and its association with other atopic diseases in these patients.

\section{Methods}

\section{Sample}

All 95 consecutive children referred to the Salmaniya Medical Complex (the principal government hospital in Bahrain with a capacity of 1300 beds) between January and December 2000 who were clinically diagnosed with asthma were enrolled in the study. Ethical approval for the study was obtained from the research committees of both the Arabian Gulf University and Salmaniya Medical Complex. Oral consent was obtained from the parents of children participating in the study.

\section{Data collection}

Demographic, clinical, allergic and therapeutic histories were collected from the records and the parents of all participants and a questionnaire checklist was filled by the interviewer.

Two $5 \mathrm{~mL}$ samples of blood were collected from each patient byvenepuncture. Total white blood cell count was carried out using a Coulter counter (Beckman Coulter). A differential count was carried out using routine procedures and absolute eosinophil counts were calculated. The cutoff for elevated eosinophils was $>350 \times 10^{6} / \mathrm{L}$.

Serum was separated and frozen at $-80{ }^{\circ} \mathrm{C}$ until assayed for total and allergen-specific IgE. Total serum $\operatorname{IgE}$ concentrations were determined by sandwich enzyme-linked immunoassay (ELISA) using a commercial kit (Bethyl Laboratories). Allergen-specific IgE assays were determined on the Pharmacia UniCap system (Pharmacia Diagnostics), a fully integrated and automated ELISA system for measurement of total and allergen-specific IgE. The cutoff for elevated IgE was $>200 \mathrm{kU} / \mathrm{L}$.

The determination of sensitivity to inhaled allergens was carried out by in vitro quantitative inhalant allergenspecific IgE test using Phadiatop ${ }^{\circ}$ (ImmunoCAP), a balanced mixture of common allergens, while sensitivity to food allergens was carried out by a quantitative food allergen-specific $\operatorname{IgE}$ using $\mathrm{f} \times 5^{\circ}$ (ImmunoCAP), a food allergen mixture which includes egg white, milk, fish, wheat, peanut and soy bean. The manufacturer's recommended cutoffs were used.

Asthma was defined according to National Institutes of Health (NIH) guidelines as mild (intermittent or persistent) asthma, moderate or severe [19]. Atopy was defined as positivity to either aero- or food allergens or both.

\section{Analysis}

Data compilation, tabulation, and statistical analysis were performed using Windows Excel and SPSS, version 14. The mean values of atopy-positive and atopy-negative patients were compared (atopy being defined as positivity to either Phadiatop or $\mathrm{fx} 5$ or both) and significance was calculated using the Student $t$-test. Mean values of IgE/eosinophil counts for the various clinical groups were compared by ANOVA. Other variable were analysed using the chi-squared test. A $P$ value of $<0.05$ was considered significant. 


\section{Results}

\section{Background characteristics}

The 95 children included in this study had been clinically diagnosed with recurrent asthma. At the visit when blood was collected for this study $88 \%$ were seen at the pulmonary outpatient paediatric clinic, 9\% were admitted for exacerbated asthma and 3\% were seen at the accident and emergency department.

The study group included 61 boys and 34 girls (ratio of 1.8:1) with a mean age of 6.8 (SD 3.8) years, range 6 months to 18 years. Most of the patients (82.1\%) were Bahraini nationals and the majority were from low-income families (Table 1).

\section{Asthma profile}

Among the children 41.0\% developed their first episode of asthma within the first 1 year of life, $58 \%$ within the first 2 years and $86 \%$ within the first 5 years. The majority of cases (71.6\%) were classified as mild (intermittent or persistent) asthma, while $20.0 \%$ were moderate and $8.4 \%$ severe (Table 2). Asthma severity increased significantly with age $(P=0.001)$; the mean age of children with mild intermittent asthma was 4.78 (SD 2.97) years, moderate asthma was 8.63 (SD 4.63) years and severe asthma was 9.25 (SD 3.73) years. There were no differences between Bahrainis and non-Bahrainis with respect to severity or prevalence of atopy (data not shown) $(P=0.751$ and $P=0.46$ respectively).

\begin{tabular}{|c|c|c|c|c|c|c|}
\hline \multirow[t]{2}{*}{ Variable } & \multicolumn{2}{|c|}{ Boys } & \multicolumn{2}{|c|}{ Girls } & \multicolumn{2}{|c|}{ Total } \\
\hline & No. & $\%$ & No. & $\%$ & No. & $\%$ \\
\hline Total & 61 & 64.2 & 34 & 35.8 & 95 & 100.0 \\
\hline \multicolumn{7}{|l|}{ Nationality } \\
\hline Bahraini & 49 & 51.6 & 29 & 30.5 & 78 & 82.1 \\
\hline Non-Bahraini & 12 & 12.6 & 5 & 5.3 & 17 & 17.9 \\
\hline \multicolumn{7}{|c|}{ Household income (US\$ / year) a } \\
\hline$<10000$ & \multicolumn{2}{|l|}{-} & \multicolumn{2}{|l|}{-} & 45 & 47.4 \\
\hline $10-20000$ & \multicolumn{2}{|l|}{-} & \multicolumn{2}{|l|}{-} & 28 & 29.5 \\
\hline$>20000$ & \multicolumn{2}{|l|}{-} & \multicolumn{2}{|l|}{-} & 16 & 16.8 \\
\hline Mean (SD) age (years) & \multicolumn{2}{|c|}{$6.6(3.8)$} & \multicolumn{2}{|c|}{$7.0(3.9)$} & \multicolumn{2}{|c|}{$6.8(3.8)$} \\
\hline
\end{tabular}

${ }^{a}$ No income data available for 6 families. $S D=$ standard deviation .

\section{Atopic profile}

Of the 95 asthmatic children studied, $56.8 \%$ were sensitized to aeroallergens and $39.0 \%$ to food allergens; $28.4 \%$ were sensitive only to aeroallergens and $10.6 \%$ only to foods but not aeroallergens. The overall rate of atopy (sensitization to aeroallergens or foods or both) in our sample was $67.4 \%$. The rate of atopy appeared to be higher in girls $(76.4 \%)$ than boys $(62.2 \%)$, but this was not statistically significant $(P=0.771)$, while the rate of food allergy was similar in both boys and girls (39.3\% versus 38.2\%) (Table 3).

\section{Risk factors for atopy}

We investigated various risk factors that are associated with atopy: $22.1 \%$ of asthmatic children were the product of consanguineous marriages and $81.1 \%$ had a family history of atopy (Table 4). Around half of the study children (51.6\%) were exposed to animals at home, the majority (92.6\%) lived in carpeted homes and one-third (31.6\%) had a parent who smoked.

Almost one-third (31.6\%) had at least 1 other associated atopic disease (eczema, allergic rhinitis, allergic conjunctivitis) and 25.3\% reported a history of known food allergies. (Table 4) Allergic rhinitis was the most prevalent atopy (24.2\%), followed by eczema (15.8\%), while allergic conjunctivitis (4.2\%) was the least prevalent among our sample.

Allergic rhinitis was significantly associated with laboratory-confirmed sensitivity to aeroallergens $(P=0.004)$, while eczema was significantly associated with both sensitivity to aeroallergens $(P$ $=0.048)$ and to foods $(P=0.018)$. The only risk factors investigated that were significantly correlated with atopy (sensitivity to either food or aeroallergens or both) were history of known food allergies and allergic rhinitis $(P=0.015$ and 0.021 respectively) (Table 4 ).

\begin{tabular}{|c|c|c|c|c|c|c|c|}
\hline \multirow[t]{2}{*}{ Severity of attacks ${ }^{\mathrm{a}}$} & \multicolumn{2}{|c|}{$\begin{array}{c}\text { Boys } \\
(n=61)\end{array}$} & \multicolumn{2}{|c|}{$\begin{array}{c}\text { Girls } \\
(n=34)\end{array}$} & \multicolumn{2}{|c|}{$\begin{array}{l}\text { Total } \\
(n=95)\end{array}$} & \multirow{2}{*}{$\begin{array}{l}\text { Age (years) } \\
\text { Mean (SD) }\end{array}$} \\
\hline & No. & $\%$ & No. & $\%$ & No. & $\%$ & \\
\hline Mild intermittent & 24 & 39.3 & 7 & 20.6 & 31 & 32.6 & $4.78(3.0)$ \\
\hline Mild persistent & 21 & 34.4 & 16 & 47.0 & 37 & 38.9 & $6.92(3.4)$ \\
\hline Moderate & 10 & 16.4 & 9 & 26.5 & 19 & 20.0 & $8.63(4.6)$ \\
\hline Severe & 6 & 9.8 & 2 & 5.9 & 8 & 8.4 & 9.25 (3.7) \\
\hline
\end{tabular}

${ }^{a}$ National Institutes of Health criteria [19].

$S D=$ standard deviation . 


\begin{tabular}{|c|c|c|c|c|c|c|c|}
\hline \multicolumn{2}{|c|}{ Sensitivity to: } & \multicolumn{2}{|c|}{$\begin{array}{c}\text { Boys } \\
(n=61)\end{array}$} & \multicolumn{2}{|c|}{$\begin{array}{c}\text { Girls } \\
(n=34)\end{array}$} & \multicolumn{2}{|c|}{$\begin{array}{c}\text { Total } \\
(n=95)\end{array}$} \\
\hline Aero-allergens ${ }^{a}$ & Food $^{b}$ & No. & $\%$ & No. & $\%$ & No. & $\%$ \\
\hline- & - & 23 & 37.7 & 8 & 23.5 & 30 & 31.6 \\
\hline+ & - & 14 & 22.9 & 13 & 38.2 & 27 & 28.4 \\
\hline- & + & 4 & 6.5 & 6 & 17.6 & 10 & 10.6 \\
\hline+ & + & 20 & 32.8 & 7 & 20.6 & 27 & 28.4 \\
\hline
\end{tabular}

${ }^{a}$ Phadiatop positive; ${ }^{\circ} f \times 5^{\circ}$ positive.

\section{Laboratory data}

Serum IgE concentrations were elevated $(>200 \mathrm{kU} / \mathrm{L})$ in $21.1 \%$ of patients and highly elevated (> $400 \mathrm{kU} / \mathrm{L})$ in $9.5 \%$, with an overall mean of 113 [standard deviation (SD 171)] kU/L (range 0-1000 kU/L) (Figure 1A). Absolute eosinophil counts were elevated $(>350$ $\left.\times 10^{6} / \mathrm{L}\right)$ in $54.8 \%$ of patients, with a mean absolute level of 432 (SD 364) $\times 10^{6} / \mathrm{L}$ (range $0-1600 \times 10^{6} / \mathrm{L}$ ) (Figure 1B).

There was a significant difference between the means of atopy-positivity and atopy-negative patients for both total serum IgE concentration and absolute eosinophil count $(P<0.001$ and $P=0.037$ respectively). When analysed separately (sensitization to aeroallergens or to food allergens), the difference in means was significant for those who were sensitive to aeroallergens $(P$
$<0.001$ and $P=0.002$ respectively) but not to food allergens ( $P=0.07$ and $P=0.302$ respectively). There was no significant relationship between clinical severity of asthma and IgE concentration or absolute eosinophil count $(P=$ 0.966 and 0.793 , respectively).

\section{Discussion}

This study was undertaken to define the profile of asthmatic children in Bahrain with respect to clinical presentation and allergen laboratory parameters and to determine the frequency of atopic asthma among our sample.

Our sample included a predominance of boys compared to girls (ratio of 1.8:1), a finding that agrees with international $[20,21]$, as well as regional reports [22-24]. The age of onset of asthma in our patients was consistent with those reported from the region [22], but earlier than those reported in industrialized counties, as $58 \%$ of our patients, as compared to one-third in Sweden [25], developed their first episode within their first 2 years of life. Extended enclosed living in air-conditioned buildings, living in carpeted homes ( $92.6 \%$ of our patients) and contact with animals at home ( $51.6 \%$ of patients) might be contributing factors.

Severity of asthma in our patients followed worldwide trends [26,27], with $\mathrm{r}$ exseverity increasing with age $(P<0.001)$, although the percentage of affected children in each category decreased, and there were no significant differences between boys and girls or Bahrainis and non-Bahrainis, suggesting a greater role for environmental than genetic factors.

\begin{tabular}{|c|c|c|c|c|c|}
\hline \multirow[t]{2}{*}{ Risk factor } & \multicolumn{2}{|c|}{ Total } & \multicolumn{3}{|c|}{ Correlation ( $\boldsymbol{P}$-values) with sensitivity to: } \\
\hline & $\begin{array}{l}\text { No. } \\
(n=95)\end{array}$ & $\%$ & $\begin{array}{l}\text { Aero-allergens }{ }^{\mathrm{a}} \\
\quad(n=54)\end{array}$ & $\begin{array}{l}\text { Foods }^{\mathrm{b}} \\
(n=37)\end{array}$ & $\begin{array}{l}\text { Either aero-allergens or foods }{ }^{c} \\
\qquad(n=64)\end{array}$ \\
\hline Consanguinous marriage & 21 & 22.1 & 0.975 & 0.166 & 0.653 \\
\hline Carpeted home & 88 & 92.6 & 0.60 & 0.02 & 0.38 \\
\hline Exposure to animals at home & 49 & 51.6 & 0.899 & 0.398 & 0.694 \\
\hline Smoker in house & 30 & 31.6 & 0.169 & 0.78 & 0.674 \\
\hline Family history of atopy & 77 & 81.1 & 0.685 & 0.473 & 0.062 \\
\hline \multicolumn{6}{|l|}{ Other atopic conditions } \\
\hline Known food allergies & 24 & 25.3 & $<0.001$ & 0.789 & 0.015 \\
\hline Allergic rhinitis & 23 & 24.2 & 0.004 & 0.642 & 0.021 \\
\hline Eczema & 15 & 15.8 & 0.048 & 0.018 & 0.256 \\
\hline Allergic conjunctivitis & 4 & 4.2 & 0.454 & 0.548 & 0.739 \\
\hline
\end{tabular}

${ }^{a}$ Phadiatop positive, ${ }^{b} \mathrm{f} \times 5^{\circ}$ positive; ${ }^{c}$ Phadiatop or $f \times 5^{\circ}$ positive. 
(A)

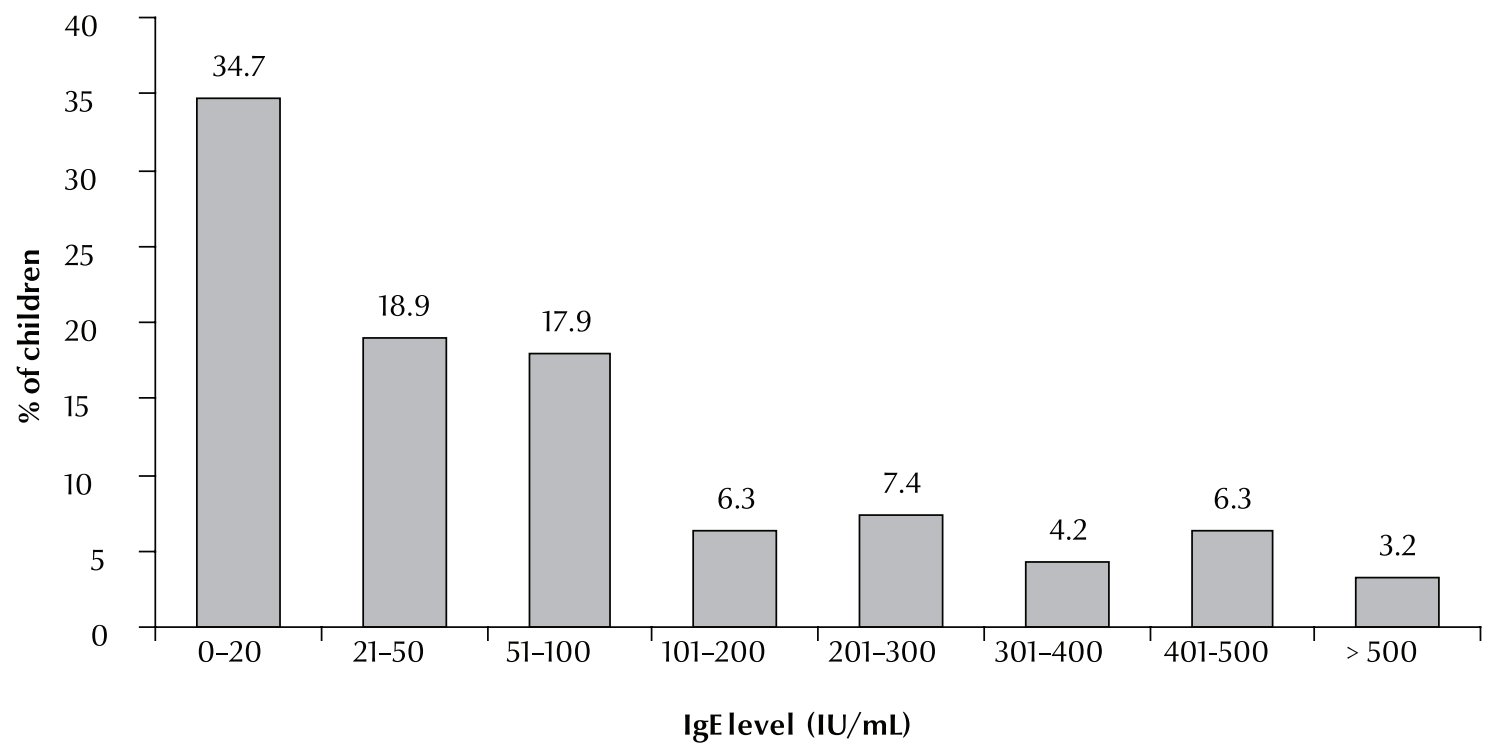

(B)

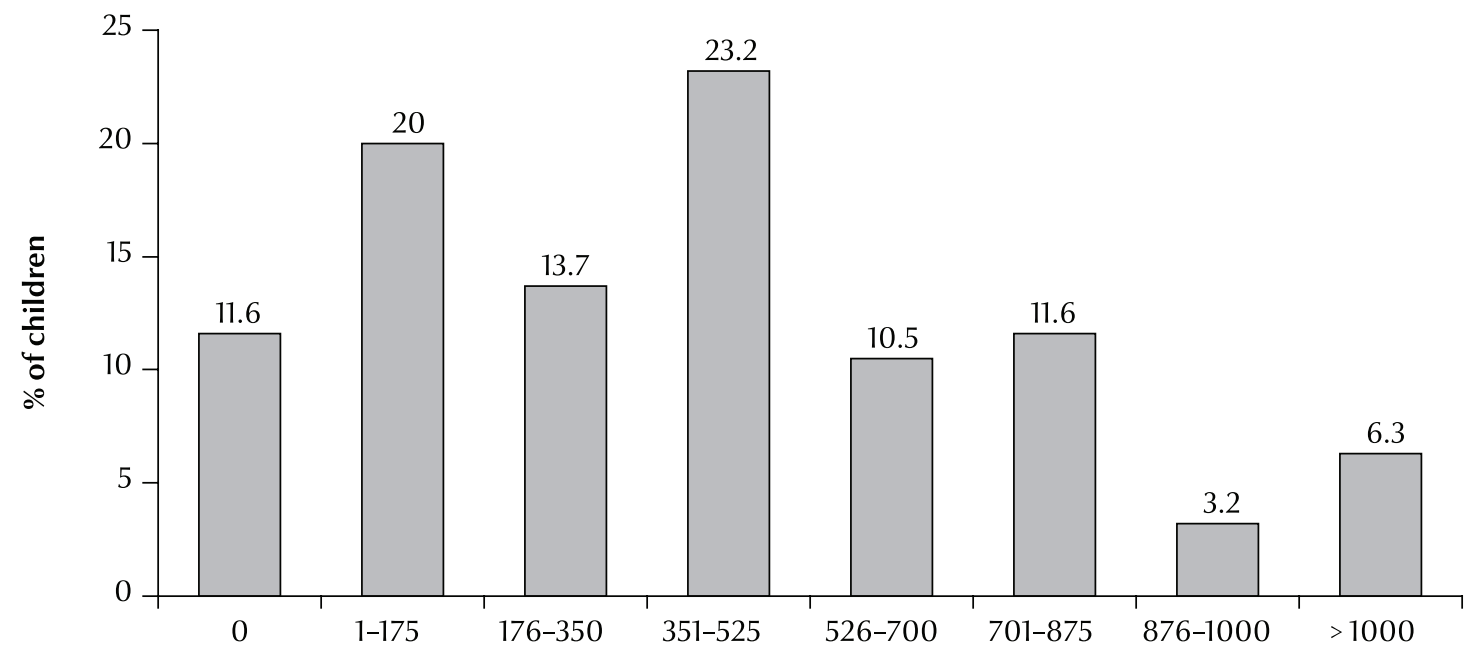

Absolute eosinophil count $/ \mathrm{L}\left(\times 10^{6}\right)$

Figure 1 (A) Total serum IgE concentrations and (B) absolute eosinophil counts of children with atopic asthma

The majority of participants $(81.1 \%)$ has been reported to be prevalent in had a family history of atopy, which agrees with other international studies [20]. The overall rate of atopy (sensitization to aeroallergens or foods or both) in our sample was $67.4 \%$, which is consistent with reports from industrialized countries such as the USA [20]. Of these, $56.4 \%$ were sensitized to aeroallergens and $39.0 \%$ to foods. Food allergy asthmatic children [28,29], to be a risk factor for asthma [29] and to trigger or exacerbate bronchoconstriction in $2 \%-8.5 \%$ of children with asthma [6]. Although we observed a significant association between food allergy and atopic asthma, the actual impact of food allergies in triggering or exacerbating asthma was not assessed in this study.
A high degree of consanguinity has been reported in the parents of asthmatic children in our region (52\%) [23]. Although Bahrain is an island and marriage within families is common, our data showed a low rate of consanguineous marriage among the parents of asthmatic children (22.1\%). The rate of consanguinity in 1990 in a sample of 500 people was $39.4 \%$ [30] 
Atopic diseases including allergic rhinitis and eczema, which are known to be highly associated with asthma in children [31-33], were similarly prevalent in our study population. Allergic rhinitis was most prevalent, followed by eczema, while allergic conjunctivitis was least prevalent among our sample. Allergic rhinitis was significantly associated with sensitivity to aeroallergens, while eczema was significantly associated sensitivity to aeroallergens and to foods.

Reference values for total IgE for non-atopic adults vary in different countries [34-36], with high values being reported in the Gulf region [34] compared with Europe $[34,36]$. These values are generally lower in children than adults and increase with age $[37,38]$. The range of serum $\operatorname{IgE}$ values of our patients was $0-1000 \mathrm{kU} / \mathrm{L}$, mean 113
$\mathrm{kU} / \mathrm{L}$. A significant correlation existed between IgE concentrations and atopy, but not with severity of asthma.

The range of absolute eosinophil count was $0-1600 \times 10^{6} / \mathrm{L}$ and was elevated in $54.8 \%$ of our patients. There was a positive relationship between increased absolute eosinophil count and atopy, particularly to aeroallergens; however this did not correlate with severity of asthma. Blood eosinophilia is seen in atopy and is influenced by several conditions including parasitic infections and corticosteroid therapy $[39,40]$. In many ways health provision in Bahrain shares many of the characteristics of health services in the advanced industrial countries. The infant mortality rate is among the lowest in the Middle East [41] and parasitic infections are uncommon.
In conclusion, $67.4 \%$ of asthmatic children in Bahrain were atopic and a high proportion (58\%) had their first episode of asthma within their first 2 years. A significant number were sensitized to foods and had other associated atopic diseases, including allergic rhinitis and eczema, but their atopic profile was generally similar to other asthmatic children in the region and worldwide. The prevalence of asthma and the identity of specific allergens in asthmatics in Bahrain are still unknown. We are investigating these parameters.

\section{Acknowledgement}

This work was supported by a grant from the Arabian Gulf University.

\section{References}

1. Arif AA et al. Prevalence and risk factors of asthma and wheezing among US adults: an analysis of the NHANES III data. European Respiratory Journal, 2003, 21(5):827-833.

2. Elias JA et al. New insights into the pathogenesis of asthma. Journal of Clinical Investigation, 2003, 111(3):291-297.

3. Burge HA, Rogers CA. Outdoor allergens. Environmental Health Perspectives, 2000, 108(Suppl. 4):653-659.

4. Platts-Mills TA et al. Determinants of clinical allergic disease. The relevance of indoor allergens to the increase in asthma. American Journal of Respiratory and Critical Care Medicine, 2000, 162(3 Pt 2):S128-133.

5. Vervloet D, Charpin D, Birnbaum J. Extrinsic asthma and environmental allergens. Allergie et Immunologie, 1991, 23(7):281-283.

6. Baena-Cagnani CE, Teijeiro A. Role of food allergy in asthma in childhood. Current Opinion in Allergy and Clinical Immunology, 2001, 1(2):145-149.

7. Ramesh S. Food allergy overview in children. Clinical Reviews in Allergy and Immunology, 2008, 34(2):217-230.

8. Anderson JA. Milestones marking the knowledge of adverse reactions to food in the decade of the 1980s. Annals of Allergy, 1994, 72(2):143-154.

9. Behbehani NA et al. Prevalence of asthma, allergic rhinitis, and eczema in 13- to 14-year-old children in Kuwait: an ISAAC study. International Study of Asthma and Allergies in Childhood. Annals of Allergy, Asthma and Immunology, 2000, 85(1):58-63.

10. Al-Maskari F et al. Asthma and respiratory symptoms among school children in United Arab Emirates. Allergie et Immunologie, 2000, 32(4):159-163.

11. Al-Dawood KM. Epidemiology of bronchial asthma among school boys in Al-Khobar city, Saudi Arabia. Saudi Medical Journal, 2001, 22(1):61-66.
12. Al Frayh AR et al. Increased prevalence of asthma in Saudi Arabia. Annals of Allergy, Asthma and Immunology, 2001, 86(3):292-296.

13. Lau $\mathrm{S}$ et al. The development of childhood asthma: lessons from the German Multicentre Allergy Study (MAS). Paediatric Respiratory Reviews, 2002, 3(3):265-272.

14. Ezeamuzie $\mathrm{Cl}$ et al. Asthma in the desert: spectrum of the sensitizing aeroallergens. Allergy, 2000, 55(2):157-162.

15. Lestringant GG et al. A clinical study of airborne allergens in the United Arab Emirates. Allergie et Immunologie, 1999, 31(8):263-267.

16. Al-Nahdi M, Al-Quorain AA. Sex distribution and common allergens of bronchial asthma in a Saudi Arabian (eastern province) population. Allergologia et Immunopathologia, 1987, 15(6):389-391.

17. Khadadah $\mathrm{M}$ et al. The association of skin test reactivity, total serum IgE levels, and peripheral blood eosinophilia with asthma in Kuwait. Journal of Asthma, 2000, 37(6):481-488.

18. Ezeamuzie $\mathrm{Cl}$ et al. IgE-mediated sensitization to mould allergens among patients with allergic respiratory diseases in a desert environment. International Archives of Allergy and Immunology, 2000, 121(4):300-307.

19. National Heart Lung and Blood Institute, National Asthma Education and Prevention Program. Expert panel report 2: guidelines for the diagnosis and management of asthma. Bethesda, Maryland, US Department of Health and Human Services, National Institutes of Health, 1997 (publication no. 97-4051).

20. Guilbert TW et al. Atopic characteristics of children with recurrent wheezing at high risk for the development of childhood asthma. Journal of Allergy and Clinical Immunology, 2004, 114(6):1282-1287. 
21. Schatz M et al. Sex differences among children 2-13 years of age presenting at the emergency department with acute asthma. Pediatric Pulmonology, 2004, 37(6):523-529.

22. Dawod ST, Hussain AA. Childhood asthma in Qatar. Annals of Allergy, Asthma and Immunology, 1995, 75(4):360-364.

23. Hijazi Z et al. Characteristics of asthmatic children in Kuwait. Journal of Asthma, 2002, 39(7):603-609.

24. Al-Ghamdy YS et al. Socioclinical profile of children with asthma in Al-Majmaah health province. Saudi Medical Journal, 2000, 21(9):847-851.

25. Croner S, Kjellman NI. Natural history of bronchial asthma in childhood. A prospective study from birth up to 12-14 years of age. Allergy, 1992, 47(2 Pt 2):150-157.

26. Buffum WP, Settipane GA. Prognosis of asthma in childhood. American Journal of Diseases of Children, 1966, 112(3):214-217.

27. Dey AN, Bloom B. Summary health statistics for U.S. children: National Health Interview Survey, 2003. Vital Health Statistics 10, 2005, Oct(223):1-78.

28. Aba-Alkhail BA, El-Gamal FM. Prevalence of food allergy in asthmatic patients. Saudi Medical Journal, 2000, 21(1):81-87.

29. Leung TF et al. Sensitization to common food allergens is a risk factor for asthma in young Chinese children in Hong Kong Journal of Asthma, 2002, 39(6):523-529.

30. Al-Arrayed, SS. Review of the spectrum of genetic diseases in Bahrain. Eastern Mediterranean Health Journal, 1999, 5(6):11141120 .

31. Levesque B et al. Asthma and allergic rhinitis in Quebec children. Canadian Respiratory Journal, 2004, 11(5):343-348.

32. Sole D et al. Is rhinitis alone or associated with atopic eczema a risk factor for severe asthma in children? Pediatric Allergy and Immunology, 2005, 16(2):121-125.
33. Kocabas $\mathrm{CN}$ et al. Burden of rhinitis in children with asthma. Pediatric Pulmonology, 2005, 40(3):235-240.

34. Zetterstrom O, Johansson SG. IgE concentrations measured by PRIST in serum of healthy adults and in patients with respiratory allergy. A diagnostic approach. Allergy, 1981, 36(8):537-547.

35. Ezeamuzie $\mathrm{Cl}$ et al. Reference values of total serum IgE and their significance in the diagnosis of allergy among the young adult Kuwaiti population. Clinical and Experimental Allergy, 1999, 29(3):375-381.

36. Simoni M et al. The Po River Delta epidemiological survey: reference values of total serum IgE levels in a normal population sample of north Italy (8-78 yrs). European Journal of Epidemiology, 2001, 17(3):231-239.

37. Dutau G, Enjaume C, Rochiccioli P. Valeurs normales des IgE seriques totales chez l'enfant de la naissance a 16 ans [Normal values of total serum IgE in children from birth to 16 years of age]. Archives Francaises de Pediatrie, 1979, 36(8):795-800.

38. Liappis N, Schlebusch H, Niesen M. [Reference values for IgE concentration in serum of children. Method: ImmunoCAPFEIA system]. Referenzbereiche fur die IgE-Konzentration im Serum von Kindern. Methode: ImmunoCAP-FEIA-System. Monatsschrift fur Kinderheilkunde, 1992, 140(5):300-302.

39. Klion AD, Nutman TB. The role of eosinophils in host defense against helminth parasites. Journal of Allergy and Clinical Immunology, 2004, 113(1):30-37.

40. Laitinen LA, Laitinen A. Inhaled corticosteroid treatment for asthma. Allergy Proceedings, 1995, 16(2):63-66.

41. 2010 world population data sheet. Population reference bureau [website] (http://www.prb.org/Publications/ Datasheets/2010/2010wpds.aspx, accessed 19 October 2010)

\section{Correction}

Implementing the district health system in the framework of primary health care in Pakistan: can the eveolving reforms enhance the pace towards the Millennium Development Goals? F. Sabih, K.M. Bile, W. Guehler, A. Hafeez, S. Nishtar and S. Siddiqi. Eastern Mediterranean Health Journal, 2010, 16(Suppl.):S132-S144.

On page S136, column 3, under "Health workforce", on lines 9 and 12, "Lady Health Visitors" should read

"Lady Health Workers". 